\title{
Effect of Electrolytes on the Adsorption of Nitrite and Nitrate from Aqueous Solutions by Activated Carbon
}

\section{SHABIR AHMED MIR}

\author{
Division of Veterinary Pharmacology \& Toxicology, Faculty of Veterinary Sciences, Sher-e-Kashmir University of Agricultural Sciences \& \\ Technology of Kashmir,F.V.Sc. \& A.H., Shuhama, P.O.Box No. 1310, G.P.O Srinagar-190001, J \& K, India \\ *Corresponding address: E-Mail Address: mirsamir.19@ rediffmail.com, Telephone/Telex No: 91-0194-2262216
}

\begin{abstract}
Nitrite and nitrate levels were quantitatively adsorbed to wood-derived activated carbon in aqueous system and the effects of electrolytes investigated in this study using batch sorption process. The data showed that nitrate adsorbed nearly 1.5 times higher than that of nitrite. The adsorption is adequately explained by Freundlich and Langmuir isotherm models ( $\mathrm{r}=0.99$ ) with parameters indicative of a beneficial adsorption.. However, the adsorption is markedly reduced in presence of electrolytes $(\mathrm{P}<0.01)$. A greater reduction in mean adsorption of the anions occurs in presence of alkaline salts $\left(\mathrm{Na}_{3} \mathrm{PO}_{4}, \mathrm{CH}_{3} \mathrm{COONa} ; 95.5\right.$ per cent $)$ and neutral chloride salts $\left(\mathrm{NaCl}, \mathrm{MgCl}_{2} ; 90.4\right.$ per cent $)$ compared to those observed in presence of neutral sulfate salts $\left(\mathrm{Na}_{2} \mathrm{SO}_{4}, \mathrm{MgSO}_{4} ; 67.8\right.$ per cent) and acidic salts $\left(\mathrm{ZnSO}_{4}, \mathrm{NaH}_{2} \mathrm{PO}_{4} ; 52.2\right.$ per cent). Acetic acid increases adsorption of nitrite by about 26 per cent $(\mathrm{P}<0.01)$ and decreases that of nitrate by ca. 30 per cent $(\mathrm{P}<0.01)$. The study reveals that nitrite and nitrate are beneficially adsorbed to the charcoal, and presence of electrolytes in general causes greater reduction, over 50 per cent, in their adsorption to the charcoal. @ JASEM
\end{abstract}

Activated charcoal possesses an excellent adsorptive capacity for a large number of chemicals including drugs and poisons (Gennaro, 2000; CECW-E, 2001; Rahman et al., 2006). Freundlich adsorption constants for many chemicals, baring nitrite and nitrate, have been documented (CECW-E, 2001). The adsorbent is valuable in analytical works and as a general-purpose emergency antidote in management of clinical cases of intoxications (Gennaro, 2000; Anon, 2008a). With respect to nitrite and nitrate, the charcoal is used to decolorize extracts for their analysis, to decontaminate gut in poisonings (Anon, 2008a), to denitrify fish aquaria (Anon, 2008b), and constitutes an alternative inexpensive material for denitrification of ground and surface waters (Mizuta et al., 2004; Rocca et al., 2007; Batheja et al., 2009; Misra and Patel, 2009). The use of the adsorbent in analytical works presumes negligible adsorption while the use for decontamination implies sufficient adsorption. However, the studies on the adsorption behavior of the anions onto activated charcoal in absence or presence of different electrolyte categories are not available. Electrolytes are commonly present in environmental waters, and are also employed routinely as adjuncts to activated charcoal in decontamination works. These considerations provided rationale to: i) study adsorption of the anions to activated charcoal, and to determine empirical parameters relevant to Freundlich and Langmuir isotherm models; and ii) study effect of various electrolyte categories at nearly iso-osmolar concentrations on the adsorption of the anions. The practical objectives have been to determine extent of adsorption, and to find conditions that would enable judicious application of the adsorbent in either analytical works or in its possible use in decontamination and denitrification works concerning the anions.

\section{MATERIALS AND METHODS}

The chemicals used were of analytical grade purity. Distilled water used for adsorption studies was freshly boiled and cooled to evacuate dissolved carbon dioxide. The particle size of activated charcoal (obtained from Glaxo Laboratories (India) Ltd, Mumbai) was less than 125 microns as it passed wholly through 125 micron mesh (ASTM) with about 10 per cent retention by 90 micron mesh (ASTM). The charcoal was freed off its residual nitrite and nitrate by sequential treatments with $0.1 \mathrm{~N} \mathrm{NaOH}, 0.2$ $\mathrm{N} \mathrm{HCl}$, and deionized water till effluent failed to show any detectable nitrite and nitrate. The purified charcoal was dried on hot plate, cooled to room temperature, and stored in a well-stoppered glass container. Stock nitrate solution, $2214 \mu \mathrm{g}$ nitrate $\mathrm{mL}^{-1}$ water, was prepared by dissolving oven-dried potassium nitrate $361 \mathrm{mg}$ in $100 \mathrm{~mL}$ water with 0.2 $\mathrm{mL}$ chloroform as preservative. Stock nitrite solution of $2300 \mu \mathrm{g}$ nitrite $\mathrm{mL}^{-1}$ was prepared by dissolving sodium nitrite $345 \mathrm{mg}$ in $100 \mathrm{~mL}$ water with $0.2 \mathrm{~mL}$ chloroform. Working nitrite and nitrate solutions were made by dilution in water. Cocktail solution of nitrite and nitrate provided each anion, respectively, as $15 \mu \mathrm{g}$ and $110 \mu \mathrm{g} \mathrm{mL}$. Other reagents used included $\mathrm{HCl}$, approximately $11.7 \mathrm{M}, 1 \%(\mathrm{w} / \mathrm{v})$ sulfanilamide in $1 \%(\mathrm{v} / \mathrm{v}) \mathrm{HCl}, 0.25$ and $1 \%(\mathrm{w} / \mathrm{v})$ $\mathrm{N}-1$ - (naphthyl)-ethylenediamine dihydrochloride in $1 \%(\mathrm{v} / \mathrm{v}) \mathrm{HCl}(\mathrm{NEDA}), 2 \%(\mathrm{w} / \mathrm{v})$ urea in water, $5 \%$ $(\mathrm{w} / \mathrm{v})$ sodium chloride in water. Isosmolar solutions of various electrolytes viz., sodium chloride, magnesium chloride, sodium sulfate, magnesium sulfate, zinc sulfate, sodium dihydrogen phosphate, trisodium phosphate and sodium acetate were made in water to provide approximately $171 \mathrm{mOsm} \mathrm{L}^{-1}$ when appropriate sized volume was added to make $10 \mathrm{~mL}$ incubation volume. The required mass of the electrolyte, $\mathrm{mg} \mathrm{mL}^{-1}$, was determined by using the following equation: Salt $(\mathrm{mg})=(1.71 \mathrm{x}$ Molecular 
Effect of Electrolytes on the Adsorption....

weight salt)/ No of dissociated particles. Factor 1.71 is equivalent of $50 \mathrm{mg}$ of sodium chloride that when added in $10 \mathrm{~mL}$ volume provided approximately 171 mOsm L L ${ }^{-1}$. Equivalent isosmolar acetic acid was made approximately by adding $1 \mathrm{~mL}$ of acetic acid, ca. $0.855 \mathrm{M}$, in water to $9 \mathrm{~mL}$ incubating mixture. The experiments were carried out at an ambient temperature of $28.9 \pm 0.4{ }^{0} \mathrm{C}$.

Adsorption of nitrite and nitrate was studied, separately, in presence of $100 \mathrm{mg}$ activated charcoal in $10 \mathrm{~mL}$ volume over the concentration range of 10 , $20,35,75,100$ and $200 \mu \mathrm{g} \mathrm{ml}^{-1}$. The samples were mixed intermittently, kept stoppered during the incubation period of 30 minutes, and filtered over Whatman filter paper No.1. The filtrates were assayed for nitrite and nitrate with respect to respective standards and reagent blanks. Time-related optimization of adsorption studies were undertaken using nitrite $25 \mu \mathrm{g} \mathrm{mL}^{-1}$ with $100 \mathrm{mg}$ charcoal in 10 $\mathrm{mL}$ volume and incubating the samples for 15 minute, 30 minute and 2 hours. The filtrates obtained were evaluated for equilibrium concentration of nitrite at the end of respective incubations. Adsorption of nitrite and nitrate in combination, 30 and $220 \mu \mathrm{g}$ respectively, by $100 \mathrm{mg}$ activated charcoal was studied in absence and presence of various concentrations of sodium chloride 50, 100 and $200 \mathrm{mg}$ in $10 \mathrm{~mL}$ water providing, correspondingly, ca. 171, 342 and $684 \mathrm{mOsm} \mathrm{L}^{-1}$. The suspensions were incubated for 15 minutes, based on time optimization studies, and then filtered over Whatman filter paper No.1. Each $\mathrm{mL}$ filtrate was assayed separately for nitrite and nitrate. Blank and standard samples were subjected to filtration to account for any alteration in concentration owing to adsorption of water by filter paper.

A comparative study was undertaken to evaluate the effect of electrolytes including acetic acid in affecting adsorption of nitrite and nitrate to activated charcoal. The osmolar concentrations were kept equivalent to approximately $171 \mathrm{mOsm} \mathrm{L}^{-1}$, and incubation continued for 15 minutes in presence of $100 \mathrm{mg}$ activated charcoal with intermittent mixing. The suspensions were filtered, and filtrates assayed for nitrite and nitrate. The remaining filtrates were analyzed for $\mathrm{pH}$ by a pocket $\mathrm{pH}$ meter ( $\mathrm{pH}$ Scan 3, Eutech Instruments, Malaysia) with sensitivity 0.01 $\mathrm{pH}$ unit. The samples containing acetic acid were compared with appropriate standards taken with equivalent mass of acetic acid to account for any loss in nitrite in acidic medium.

For nitrite assay an appropriate sized aliquot of the filtrate in $2.5 \mathrm{~mL}$ water was added $0.1 \mathrm{~mL}$ sulfanilamide solution and $0.5 \mathrm{~mL} \mathrm{HCl}$, allowed to diazotize for 2 to 3 minutes, added $0.2 \mathrm{~mL}$ of $0.25 \%$ NEDA reagent, and allowed to couple for at least 30 minutes. The color was monitored at $540 \mathrm{~nm}$ using reagent blank and appropriate standards run simultaneously. Nitrate was determined by acid reduction method (Mir, 2008, 2009). Appropriate sized aliquot of the filtrate in $1 \mathrm{~mL}$ water was added $0.1 \mathrm{~mL}$ sulfanilamide solution and $2 \mathrm{~mL}$ concentrated $\mathrm{HCl}$. The samples were incubated in boiling water bath for exactly 3 minutes, and cooled to room temperature by immersion in tap water, added $0.2 \mathrm{~mL}$ of $1 \%$ NEDA reagent, mixed and allowed to couple for at least 30 minutes, and finally monitored at 540 $\mathrm{nm}$. The experiments involving cocktail of nitrite and nitrate were first subjected to urea treatment to eliminate nitrite (Mir, 2008). Each milliliter sample filtrate was added $0.1 \mathrm{~mL}$ urea solution and $0.2 \mathrm{~mL}$ $\mathrm{HCl}$, incubated in boiling water bath for 10 minutes, and cooled to room temperature. The samples were assayed then for nitrate as per outlined procedure.

The mass of anion adsorbed was determined by difference between initial concentration $\left(\mathrm{C}_{0}, \mu \mathrm{g} \mathrm{mL} \mathrm{m}^{-1}\right)$ and the concentration determined at equilibrium $\left(\mathrm{C}_{\mathrm{e}}\right.$, $\mu \mathrm{g} \mathrm{mL}^{-1}$ following adsorption). The data were fit to Freundlich and Langmuir adsorption isotherm equations for determination of adsorption parameters (Kadirvelu and Namasivayam, 2000; CECW-E, 2001; Abdul and Aberuagba, 2005; Ahalya et al., 2005 ) with calculations based on regression analysis.

The linearized Freundlich adsorption isotherm (CECW-E, 2001) is equation is given by

$\log \left[\mathrm{A}_{\mathrm{c}}\right]=\log \mathrm{K}_{\mathrm{f}}+1 / \mathrm{n}\left[\mathrm{C}_{\mathrm{e}}\right]$

For calculation of Freundlich adsorption isotherm parameters $\log$ equilibrium concentration $\left(\mathrm{C}_{\mathrm{e}}\right), \mu \mathrm{g}$ $\mathrm{mL}^{-1}$, served as independent variable $\mathrm{X}$ and $\log$ adsorption coefficient $\left(A_{c}, \mu g\right.$ analyte adsorbed per $\mathrm{mg}$ of activated charcoal) as dependent variable $\mathrm{Y}$ with regression coefficient, $m$, defined by $1 / n: n=$ $1 / \mathrm{m}$, where $\mathrm{n}$ is defined as adsorption intensity constant, $\mathrm{Y}$-intercept $=\log \mathrm{K}_{\mathrm{f}}, \mathrm{K}_{\mathrm{f}}=$ Antilog of $\mathrm{Y}$ intercept, called Freundlich equilibrium constant, defined as adsorption capacity constant. The linearized Langmuir adsorption isotherm equation is given by

$\left[\mathrm{C}_{\mathrm{e}}\right] /\left[\mathrm{A}_{\mathrm{c}}\right]=\left[\mathrm{C}_{\mathrm{e}}\right] /\left[\mathrm{N}_{\mathrm{m}}\right]+1 /\left[\mathrm{K}_{\mathrm{l}}\right]\left[\mathrm{N}_{\mathrm{m}}\right]$

For calculation of parameters of Langmuir adsorption isotherm, the equilibrium concentration $\left(\mathrm{C}_{\mathrm{e}}\right)$ served as independent variable $\mathrm{X}$ and ratio $\left[\mathrm{C}_{\mathrm{e}} / \mathrm{A}_{\mathrm{c}}\right]$ served as dependent variable $\mathrm{Y}$, and $\mathrm{m}$ as regression coefficient: $\mathrm{N}_{\mathrm{m}}=1 / \mathrm{m}$, where $\mathrm{N}_{\mathrm{m}}$ defines mass of adsorbate required to form a monolayer on adsorbent $\left(=\mathrm{k}_{3}\right), \quad \mathrm{K}_{\mathrm{l}}=$ Regression coefficient/Y-intercept. Langmuir rate constant $\mathrm{K}_{1}$ incorporates rate constants of adsorption $\left(\mathrm{k}_{1}\right)$ and desorption $\left(\mathrm{k}_{2}\right)$ and is equal to $\mathrm{k}_{1} / \mathrm{k}_{2}$. The separation factor, $\mathrm{R}_{1}$ parameter, was 
Effect of Electrolytes on the Adsorption....

determined for each concentration by using the formula (Ahalya et al., 2005)

$\mathrm{R}_{\mathrm{l}}=1 /\left[1+\left(\mathrm{K}_{\mathrm{l}}\right)\left(\mathrm{C}_{0}\right)\right]$

For evaluation of effects of electrolytes, the mass of nitrite and nitrate adsorbed to charcoal was determined in terms of simultaneously run standard in water. Per cent adsorption of the anion was evaluated with respect to basal anion concentration, and per cent inhibition of adsorption was determined in terms of adsorption of the anion to charcoal in water taken as 100 per cent adsorption.

\section{RESULTS AND DISCUSSION}

Nitrite and nitrate are quantitatively adsorbed to the activated charcoal (Tables 1,2). The mean mass of nitrate adsorbed is nearly 1.5 times $(1.48 \pm 0.04, \mathrm{n}=$ 6 ) higher than the mass of adsorbed nitrite. The isotherms and linearized forms of the adsorption isotherms are displayed as Figures 1 to 3 . The adsorption processes are adequately explained by Freundlich and Langmuir adsorption isotherm models $(\mathrm{r}=0.99)$. The Freundlich isotherm parameters provide valuable information for finding antidotal and denitrification effectiveness of activated charcoal (CECW-E, 2001).

Table 1: Adsorption of nitrite to activated charcoal ${ }^{\mathrm{a}}$

\begin{tabular}{|c|c|c|c|c|c|c|}
\hline $\mathrm{C}_{\mathrm{o}} \mu \mathrm{g} \mathrm{mL^{-1 }}$ & \multicolumn{2}{|c|}{$\mathrm{C}_{\mathrm{e}} \mu \mathrm{g} \mathrm{mL}^{-1}$} & $\mathrm{C}_{\mathrm{a}} \mu \mathrm{g} \mathrm{mL} \mathrm{L}^{-1}$ & $\mathrm{~A}_{\mathrm{c}} \mu \mathrm{g} \mathrm{mg}^{-1}$ & \multicolumn{2}{|c|}{$\mathrm{C}_{\mathrm{e}} / \mathrm{A}_{\mathrm{c}}$} \\
\hline 10 & \multicolumn{2}{|c|}{$3.0 \pm 0.1$} & $7.0 \pm 0.1$ & $0.70 \pm 0.01$ & \multicolumn{2}{|c|}{4.29} \\
\hline 20 & \multicolumn{2}{|c|}{$10.1 \pm 0.1$} & $9.9 \pm 0.1$ & $0.99 \pm 0.01$ & \multicolumn{2}{|c|}{10.20} \\
\hline 35 & \multicolumn{2}{|c|}{$22.3 \pm 0.1$} & $12.7 \pm 0.1$ & $1.27 \pm 0.01$ & \multicolumn{2}{|c|}{17.56} \\
\hline 75 & \multicolumn{2}{|c|}{$59.8 \pm 0.6$} & $15.2 \pm 0.6$ & $1.52 \pm 0.06$ & \multicolumn{2}{|c|}{39.34} \\
\hline 100 & \multicolumn{2}{|c|}{$83.3 \pm 0.5$} & $16.7 \pm 0.5$ & $1.67 \pm 0.05$ & \multicolumn{2}{|c|}{49.88} \\
\hline 200 & \multicolumn{2}{|c|}{$179.7 \pm 0.8$} & $20.3 \pm 0.8$ & $2.03 \pm 0.08$ & \multicolumn{2}{|c|}{88.52} \\
\hline \multicolumn{7}{|c|}{ Freundlich isotherm parameters $\left(\log C_{e}\right.$ vs. $\left.\log A_{c}\right)$} \\
\hline $\begin{array}{l}r \pm \mathrm{se} \\
0.997 \pm 0.002\end{array}$ & \multicolumn{2}{|c|}{$\begin{array}{l}\mathrm{m} \pm \mathrm{se} \\
0.256 \pm 0.008\end{array}$} & \multicolumn{2}{|c|}{\begin{tabular}{|c|c|}
$\mathrm{n}$ & \\
3.909 &
\end{tabular}} & \multicolumn{2}{|c|}{$\begin{array}{l}\mathrm{K}_{\mathrm{f}} \\
0.543\end{array}$} \\
\hline \multicolumn{7}{|c|}{ Langmuir isotherm parameters $\left(\mathrm{C}_{\mathrm{e}}\right.$ vs. $\left.\mathrm{C}_{\mathrm{e}} / \mathrm{A}_{\mathrm{c}}\right)$} \\
\hline \multicolumn{2}{|c|}{$\begin{array}{c}\mathrm{r} \pm \mathrm{se} \\
0.994 \pm 0.005\end{array}$} & \multicolumn{2}{|c|}{$\begin{array}{c}\mathrm{m} \pm \mathrm{se} \\
0.472 \pm 0.021\end{array}$} & \multicolumn{2}{|c|}{$\begin{array}{c}\mathrm{N}_{\mathrm{m}} \\
2.119\end{array}$} & $\begin{array}{c}\mathrm{K}_{\mathrm{l}} \\
0.069\end{array}$ \\
\hline
\end{tabular}

${ }^{a} 100 \mathrm{mg}$ charcoal in $10 \mathrm{~mL}$ volume; $C_{o}$, initial concentration; $C_{e}$, equilibrium concentration; $C_{a}$, adsorbed concentration; $A_{c}$, adsorption coefficient, $\mu g$ adsorbed per mg charcoal;; $m$, regression coefficient;; $n$, adsorption intensity constant; $K_{f}$, Freundlich adsorption capacity constant; $K_{l}$ Langmuir equilibrium constant $\left(=k_{1} / k_{2}\right) ; N_{m}$, adsorbate microgram required to form a monolayer on adsorbent $\left(=k_{3}\right)$. The data values are mean \pm se of six observations each.

Table 2: Adsorption of nitrate to activated charcoal ${ }^{\mathrm{a}}$

\begin{tabular}{|c|c|c|c|c|}
\hline $\mathrm{C}_{\mathrm{o}} \mu \mathrm{g} \mathrm{mL^{-1 }}$ & $\mathrm{C}_{\mathrm{e}} \mu \mathrm{g} \mathrm{mL}^{-1}$ & $\mathrm{C}_{\mathrm{a}} \mu \mathrm{g} \mathrm{mL}^{-1}$ & $\mathrm{~A}_{\mathrm{c}} \mu \mathrm{g} \mathrm{mg}^{-1}$ & $\mathrm{C}_{\mathrm{e}} / \mathrm{A}_{\mathrm{c}}$ \\
\hline 10 & $0.9 \pm 0.3$ & $9.1 \pm 0.3$ & $0.91 \pm 0.03$ & 0.99 \\
\hline 20 & $5.5 \pm 0.2$ & $14.5 \pm 0.2$ & $1.45 \pm 0.05$ & 3.79 \\
\hline 35 & $15.8 \pm 0.2$ & $19.2 \pm 0.2$ & $1.92 \pm 0.02$ & 8.23 \\
\hline 75 & $50.9 \pm 0.4$ & $24.1 \pm 0.4$ & $2.41 \pm 0.04$ & 21.12 \\
\hline 100 & $74.1 \pm 0.3$ & $25.9 \pm 0.3$ & $2.59 \pm 0.03$ & 28.61 \\
\hline 200 & $170.2 \pm 1.1$ & $29.8 \pm 1.1$ & $2.98 \pm 0.11$ & 57.11 \\
\hline & \multicolumn{4}{|c|}{ Freundlich isotherm parameters $\left(\log C_{e}\right.$ vs. $\left.\log A_{c}\right)$} \\
\hline \multicolumn{2}{|c|}{$\begin{array}{c}\mathrm{r} \pm \mathrm{se} \\
0.996 \pm 0.003\end{array}$} & $\begin{array}{l}\mathrm{m} \pm \mathrm{se} \\
0.228 \pm 0.008\end{array}$ & $4.384^{n}$ & $\begin{array}{l}K_{f} \\
0.969\end{array}$ \\
\hline \multicolumn{5}{|c|}{ Langmuir isotherm parameters $\left(\mathrm{C}_{\mathrm{e}} \mathrm{vs} . \mathrm{C}_{\mathrm{e}} / \mathrm{A}_{\mathrm{c}}\right)$} \\
\hline \multicolumn{2}{|c|}{$\begin{array}{c}r \pm \mathrm{se} \\
0.997 \pm 0.002\end{array}$} & $\begin{array}{c}\mathrm{m} \pm \mathrm{se} \\
.328 \pm 0.010\end{array}$ & $\begin{array}{c}\mathrm{N}_{\mathrm{m}} \\
3.053\end{array}$ & $\begin{array}{c}\mathrm{K}_{\mathrm{l}} \\
.124\end{array}$ \\
\hline
\end{tabular}

${ }^{a} 100 \mathrm{mg}$ charcoal in $10 \mathrm{~mL}$ volume; $C_{o}$, initial concentration; $C_{e}$, equilibrium concentration; $C_{a}$, adsorbed concentration; $A_{c}$, adsorption coefficient, $\mu \mathrm{g}$ adsorbed per $m g$ charcoal; $m$, regression coefficient;; $n$, adsorption intensity constant; $K_{f}$, Freundlich adsorption capacity constant; $K_{l}$, Langmuir equilibrium constant $\left(=k_{1} / k_{2}\right) ; N_{m}$, adsorbate microgram required to form a monolayer on adsorbent $\left(=k_{3}\right)$.

The data values are mean \pm se of six observations.

The $\mathrm{n}$ values between 1 and 10 reflect a beneficial adsorption (Kadirvelu and Namasivayam, 2000; Ahalya et al., 2005) while the $\mathrm{K}_{\mathrm{f}}$ values provide information about the adsorption capacity of the adsorbent. In the present study, the $\mathrm{n}$ values for nitrate and nitrite have been, respectively, 4.384 and 3.909. The $\mathrm{K}_{\mathrm{f}}$ values have been, correspondingly, 0.969 and 0.543 indicating that the charcoal can maximally 
Effect of Electrolytes on the Adsorption....

adsorb nitrate and nitrite to the extents of about, respectively, $0.97 \mathrm{mg}$ (ca. $15.6 \mu$ moles) and $0.54 \mathrm{mg}$ (ca. $11.7 \mu$ moles) $\mathrm{g}^{-1}$. The molar ratio of nitrate and nitrite for adsorption, 1.33, corresponds to their molecular weights ratio, 1.35 , suggesting that the two anions are adsorbed to charcoal in a comparable manner. The parameters of Langmuir isotherm provide valuable information about the rate constants governing adsorption $\left(\mathrm{k}_{1}\right)$, desorption $\left(\mathrm{k}_{2}\right)$ and adsorption of adsorbate as monolayer on adsorbent $(\mathrm{k}$ 3). The Langmuir equilibrium constant $\mathrm{K}_{1}$ defines the ratio of $\mathrm{k}_{1}$ and $\mathrm{k}_{2}$, and the parameter $\mathrm{Nm}$ is a function of $\mathrm{k}_{3}$ and defines monolayer formation on adsorbent. The $\mathrm{K}_{1}$ value for nitrate has been nearly 1.8 times the value obtained for nitrite implying a greater rate of adsorption than desorption for nitrate $\left(\mathrm{k}_{1}>\mathrm{k}_{2}\right)$ compared to those for nitrite $\left(\mathrm{k}_{1}<\mathrm{k}_{2}\right)$. The $\mathrm{N}_{\mathrm{m}}$ value for nitrate has been nearly1.4 times the value for nitrite. This further confirms the findings obtained from Freundlich isotherm analysis. The values of separation factor, $\mathrm{R}_{1}$, over the test concentrations have ranged, respectively, from 0.067 to 0.589 for nitrite and from 0.039 to 0.447 for nitrate. The $R_{1}$ values between 0 and 1 are considered as indicators of favorable adsorption (Ahalya et al., 2005). The present study reveals that the adsorption of nitrite and nitrate to activated charcoal is beneficial, and the adsorption behavior of the two anions is almost parallel.
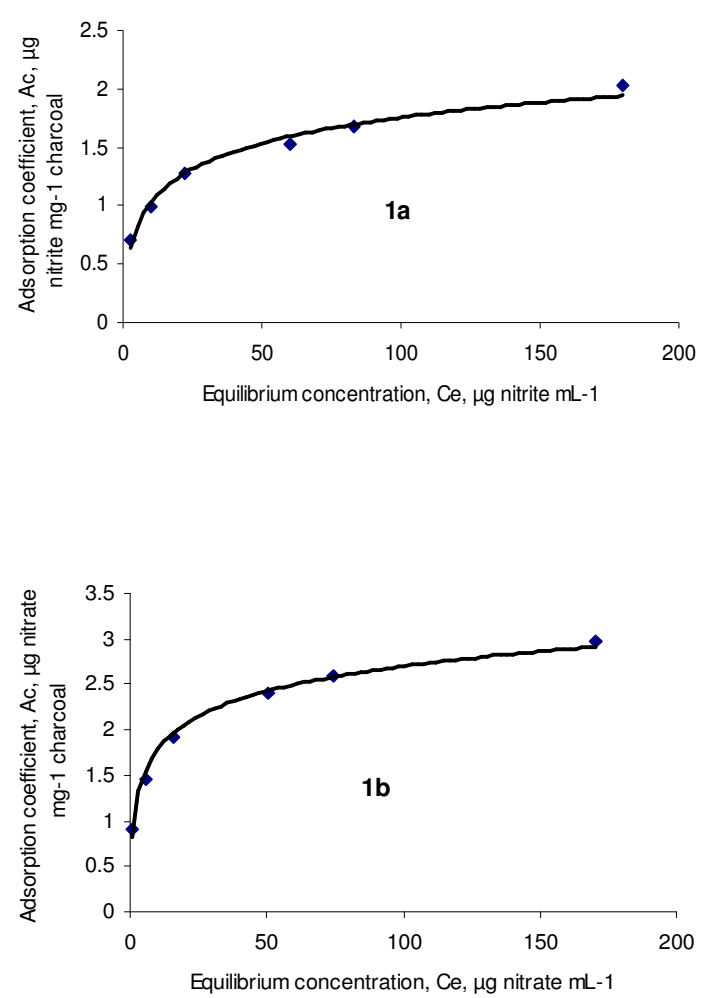

Fig. 1: Adsorption isotherms for nitrite (1a) and nitrate (1b) onto wood-derived activated charcoal
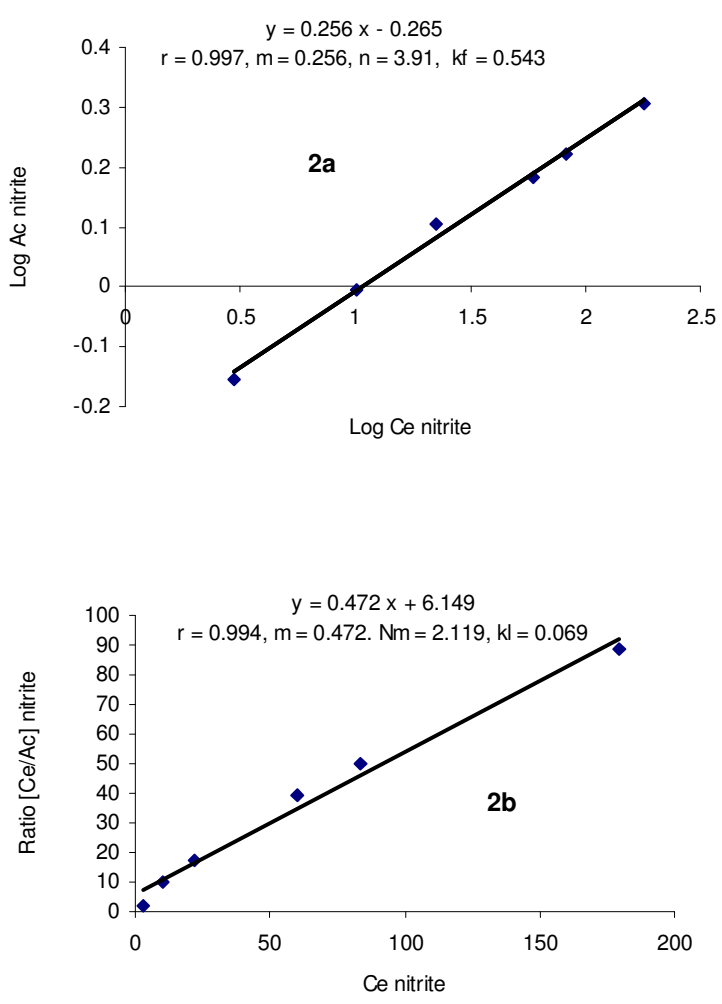

Fig. 2: Linearized Freundlich (2a) and Langmuir (2b) adsorption isotherms for nitrite; $\mathrm{Ce}=$ equilibrium concentration, $\mu \mathrm{g} \mathrm{mL}{ }^{-1} ; \mathrm{Ac}=$ adsorption coefficient, $\mu \mathrm{g}$ $\mathrm{mg}^{-1}$ charcoal

Time optimization studies with nitrite $25 \mu \mathrm{g} \mathrm{mL}$ have not revealed any significant difference in adsorbed nitrite over the incubations time periods of $15 \mathrm{~min}, 30 \mathrm{~min}$ and $2 \mathrm{hr}$. The adsorbed concentrations at equilibrium remained, respectively, $11.4 \pm 0.3,12.1$ \pm 0.2 and $12.4 \pm 0.3 \mu \mathrm{g} \mathrm{mL}^{-1}(\mathrm{n}=6$ each, $\mathrm{P}>0.1)$. Obviously, the adsorption is faster in onset with equilibrium attained within 15 minutes. The incubation time for the study in presence of electrolytes has been limited to 15 minutes in view of time optimization studies, and on the consideration that for both analytical and gut decontamination applications an increase in time for adsorption is not desirable. Nitrite and nitrate have been taken together as a cocktail with nitrate mass over 7-fold higher than that for nitrite. High nitrate in the cocktail has offered convenience of its measurement in view of its detection limit being nearly 10-fold higher than that observed for nitrite under test conditions (Mir, 2008). Besides, the ratio nearly simulates the presence of anions in natural and biological samples. Acid reduction method coupled to urea pretreatment has enabled selective determination of nitrate by modified Griess reaction in presence of nitrite without affecting 
Effect of Electrolytes on the Adsorption....

determination of nitrate or its regression coefficient (Mir, 2008). Sodium chloride over the test osmolarity of 171,342 and $684 \mathrm{mOsm} \mathrm{L} \mathrm{L}^{-1}$ induced profound reduction in the adsorption of nitrite and nitrate to the extent of 90 to 98 per cent $(\mathrm{P}<0.01)$ with no significant difference between different salt concentrations $(\mathrm{P}>0.1)$. Consequently, comparative studies with other electrolytes were made at nearly isosmolar concentrations of $171 \mathrm{mOsm} \mathrm{L}^{-1}$. The selection of different electrolytes has been on the consideration of appreciating the role of different anions viz., sulfates, phosphates, chlorides and acetates under naturally occurring $\mathrm{pH}$ alterations induced by dissociation of the electrolytes while in aqueous media. As apparent from Table 3, the adsorption of the anions is markedly reduced, from over 50 per cent to about 96 per cent, in presence of electrolyte salts irrespective of their nature. The magnitude of reduction is apparently determined by the nature of anions in case of neutral electrolytes, and by $\mathrm{pH}$ at equilibrium in case of acid and alkaline electrolytes. The mean per cent adsorption of nitrite and nitrate is comparable with each electrolyte $(\mathrm{P}>0.1)$, and over all per cent nitrate adsorbed is twice, $1.9 \pm 0.2(n=8)$, than the value for nitrite. The mean adsorbed mass of nitrite and nitrate in presence of phosphate, acetate and sulfate from electrolyte salts is negatively related to increase in mean $\mathrm{pH}$ at equilibrium $(\mathrm{r}=-0.98)$. Mean per cent reduction in adsorption, 52.2, is least with acid salts showing mean $\mathrm{pH}$ value at equilibrium 5.3 to 5.4 , with no significant difference between zinc sulfate and sodium dihydrogen phosphate $(\mathrm{P}>0.1)$. Acid salts reduce adsorption of nitrite to a greater extent than that of nitrate since per cent nitrate adsorbed is 2.3 times higher than that of nitrite (Table 3 ). The adsorption of nitrite and nitrate in presence of acetic acid, mean $\mathrm{pH}$ at equilibrium 3.8, is about 27 and 14- times the respective adsorption values obtained in presence of sodium acetate, mean $\mathrm{pH}$ 11.0. A similar observation is apparent with phosphates wherein reduction in adsorption is much greater with alkaline salt than due to acid salt, $\mathrm{pH}$ difference at equilibrium 6.6 units, and with sulfates where acid form, zinc sulfate, shows lesser reduction in adsorption than its neutral forms, magnesium and sodium sulfates with $\mathrm{pH}$ differences at equilibrium about 1.4 units. Thus, magnitude of reduction in adsorption of nitrite and nitrate by acetate, phosphate and sulfate is function of the $\mathrm{pH}$ at equilibrium.

Over all, the adsorbed mass of nitrite and nitrate is maximum in presence of acetic acid than in presence of other electrolytes $(\mathrm{P}<0.01)$. In particular, the adsorption of nitrite is significantly more in acetic acid, about 26 per cent, than in presence of water $(\mathrm{P}<0.05)$. The latter effect is presumably due to the formation of more effectively binding nitrous acid. Decrease in estimated free nitrite is not related to the destruction of nitrite by the acid because acetic acid
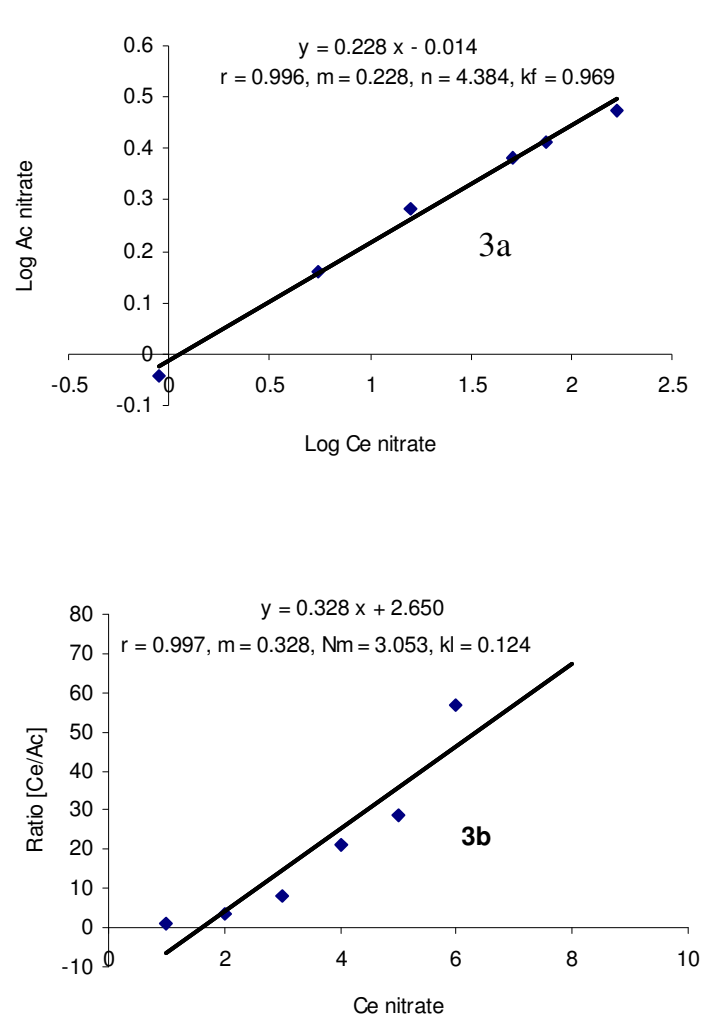

Fig. 3: Linearized Freundlich (3a) and Langmuir (3b) adsorption isotherms for nitrate; $\mathrm{Ce}=$ equilibrium concentration, $\mu \mathrm{g} \mathrm{mL}^{-1} ; \mathrm{Ac}=$ adsorption coefficient, $\mu \mathrm{g} \mathrm{mg}^{-1}$ charcoal

did not significantly affect nitrite estimation when absorbance values for the standards in water were compared with standards prepared in equivalent mass of acetic acid $(\mathrm{P}>0.1)$. Obviously, the adsorbed mass of nitrite and nitrate onto the charcoal is higher under acidic conditions. Similar observations have been recorded by other workers. Acid-treated carbon cloth has significantly increased the adsorption of nitrite and nitrate (Afkhami et al., 2007) and acidic pH has been most effective for favoring adsorption of nitrate to charcoal (Ozturk and Bektas, 2004). Mean per cent reduction in adsorption of the anions, 95.5, has been highest in presence of alkaline salts, mean $\mathrm{pH}$ at equilibrium, 11 to 12 . No significant difference exists between sodium acetate and tri-sodium phosphate in reduction of adsorption of either nitrite or nitrate $(\mathrm{P}>0.1)$, and also per cent nitrate adsorbed is 1.3 times higher than that of nitrite (Table 3 ). In presence of neutral electrolytes mean per cent reduction in adsorption, 79, has been somewhat intermediate to those with acid and alkaline salts, $\mathrm{pH}$ at equilibrium 6.4 to 6.9. The effect of chlorides, mean per cent reduction 90.4, has been almost as good as that due to alkaline salts compared to that, 67.8 per cent, observed in presence of sulfate salts. Thus, for neutral electrolytes magnitude of reduction is apparently 
Effect of Electrolytes on the Adsorption....

affected by the nature of their anions. Consistent with the effect of acid and alkaline salts, mean per cent nitrate adsorbed is nearly twice than that of nitrite. Sodium chloride has been successfully used to regenerate chelating polymers for nitrate removal, and the regenerated polymers offer an additional sorption capacity for nitrate (Zho et al., 2006). Sodium chloride has reduced adsorption of rifampicin to activated charcoal (Orisakwe et al., 2001). Polyelectrolyte mixture containing neutral electrolytes (sodium sulfate, sodium chloride, potassium chloride) with alkaline electrolyte (sodium bicarbonate) are known to reduce the adsorption of the drugs implying that alkaline $\mathrm{pH}$ and neutral electrolytes are favorable to reduction in adsorption (Gennaro, 2000).

Table 3: Adsorption of nitrite and nitrate to activated charcoal ${ }^{\mathrm{a}}$ in presence of various electrolytes at isosmolar concentrations ${ }^{\mathrm{b}}$

\begin{tabular}{|l|l|l|l|l|l|}
\hline \multirow{2}{*}{ Treatment } & \multicolumn{2}{l|}{ Nitrite $30 \mu \mathrm{g}$} & \multicolumn{2}{l}{ Nitrate 220 $\mu \mathrm{g}$} & \multirow{2}{*}{$\mathrm{pH}$} \\
\cline { 2 - 5 } & $\begin{array}{l}\text { Adsorbed } \\
\mu \mathrm{g}\end{array}$ & $\begin{array}{l}\text { Adsorption }^{\mathrm{c}} \\
\%\end{array}$ & $\begin{array}{l}\text { Adsorbed } \\
\mu \mathrm{g}\end{array}$ & $\begin{array}{l}\text { Adsorption }^{\mathrm{c}} \\
\%\end{array}$ & \\
\hline Water & $15.2 \pm 0.7$ & $50.4 \pm 2.4$ & $156 \pm 5$ & $71 \pm 2$ & $6.8 \pm 0.1$ \\
\hline $\mathrm{NaCl}$ & $1.3 \pm 0.2$ & $4.2 \pm 0.8$ & $18 \pm 3$ & $9 \pm 2$ & $6.8 \pm 0.2$ \\
\hline $\mathrm{MgCl}_{2}$ & $1.1 \pm 0.3$ & $3.8 \pm 1.1$ & $19 \pm 1$ & $7 \pm 1$ & $6.4 \pm 0.1$ \\
\hline $\mathrm{Na}_{2} \mathrm{SO}_{4}$ & $3.6 \pm 0.4$ & $12.0 \pm 1.4$ & $55 \pm 3$ & $25 \pm 2$ & $6.9 \pm 0.1$ \\
\hline $\mathrm{MgSO}_{4}$ & $4.0 \pm 0.4$ & $13.2 \pm 1.4$ & $69 \pm 3$ & $31 \pm 1$ & $6.5 \pm 0.2$ \\
\hline $\mathrm{CH}_{3} \mathrm{COONa}$ & $0.7 \pm 0.2$ & $2.3 \pm 0.6$ & $8 \pm 2$ & $4 \pm 1$ & $11.0 \pm 0.1$ \\
\hline $\mathrm{Na}_{3} \mathrm{PO}_{4}$ & $0.7 \pm 0.3$ & $2.4 \pm 0.8$ & $5 \pm 2$ & $2 \pm 1$ & $12.0 \pm 0.1$ \\
\hline $\mathrm{NaH}_{2} \mathrm{PO}_{4}$ & $5.9 \pm 0.2$ & $19.5 \pm 0.7$ & $94 \pm 3$ & $43 \pm 1$ & $5.4 \pm 0.3$ \\
\hline $\mathrm{ZnSO}_{4}$ & $5.2 \pm 0.2$ & $17.4 \pm 0.6$ & $90 \pm 4$ & $41 \pm 2$ & $5.3 \pm 0.1$ \\
\hline $\mathrm{CH}_{3} \mathrm{COOH}$ & $19.1 \pm 0.6$ & $63.7 \pm 2.0$ & $111 \pm 6$ & $50 \pm 3$ & $3.8 \pm 0.2$ \\
\hline
\end{tabular}

$100 \mathrm{mg}$ in $10 \mathrm{~mL}$ volume; ${ }^{b}$ Approximately $171 \mathrm{mOsm} \mathrm{L}^{-1} ;{ }^{c}$ Adsorption per cent with respect to initial anion mass. The values are mean \pm se of six observations each.

Nitrate per se decreases adsorption of nitrite onto the charcoal. In absence of nitrate, the mass of adsorbed nitrite, $0.26 \pm 0.01 \mu \mathrm{g} \mathrm{mg}^{-1}$ while using initial nitrite $3 \mu \mathrm{g} \mathrm{mL}^{-1}$, has been significantly higher compared to the value of $0.15 \pm 0.01 \mu \mathrm{g} \mathrm{mg}^{-1}$ observed in presence of high nitrate (Table 3$)(\mathrm{P}<0.01, \mathrm{n}=6$ each). This observation has been separately confirmed by repeating the study using nitrite $15 \mu \mathrm{g} \mathrm{mL} \mathrm{m}^{-1}$ in presence of $0,10,20$ and $50 \mu \mathrm{g}$ nitrate $\mathrm{mL}^{-1}$. There has been a proportional decrease in adsorption of nitrite with an increase in nitrate concentration, and the mean per cent reduction values have been 23,45 and 75 respectively compared to the adsorption of nitrite in absence of nitrate $(\mathrm{r}=0.98, \mathrm{n}=3$ each). The influence of nitrate on nitrite adsorption may be partly related to its relative high concentration, and partly due to the observed fact that alkaline salts tend to show decreased binding compared to neutral salts. In the instant case sodium nitrite and potassium nitrate used in the study represent alkaline and neutral salts, respectively. The Langmuir isotherm parameter $\mathrm{K}_{\mathrm{l}}$ has confirmed greater desorption than adsorption for nitrite as compared to those for nitrate. With acidic and alkaline electrolytes, the mass adsorbed is more in presence of acidic electrolyte implying an increase in desorption and / or decrease in their sorption to the binding sites on the adsorbent. Activated charcoal offers both polar as well as nonpolar binding sites for sorption phenomena (Ahalya et al., 2005; Rahman et al., 2006). Influence of acetic acid on nitrite is probably consequence of direct interaction between acid and nitrite, converting nitrite to nitrous acid and apparently favoring its enhanced adsorption to the charcoal. The $\mathrm{pH}$ at equilibrium alters protonation (Hoegberg et al, 2002; Misra and Patel, 2009) or extent of ionization in adsorbate that are possibly responsible for decreased binding and/or increased desorption of adsorbate from adsorbed sites. Alteration in $\mathrm{pH}$ changes surface charge density on activated carbon that affects the adsorption of adsorbates differently (Chen and Lin, 2001).

The present work has revealed potential of activated charcoal to adsorb nitrite and nitrate, and the influence of various electrolytes in modifying the adsorption. The study provides empirical Freundlich and Langmuir adsorption isotherm constants for nitrite and nitrate with respect to their binding to activated charcoal at room temperature. The work has revealed the importance of giving consideration to the ionic factors while employing activated charcoal as a decolorizing or decontaminating agent to prevent or minimize the adsorption of nitrite and nitrate to activated charcoal. Alkaline and neutral chloride salts, in that order, would maximize recovery of nitrite and nitrate if the charcoal is employed during their extraction. For the purpose of denitrification of contaminated waters, absence of electrolytes, and presence of acidic $\mathrm{pH}$ at equilibrium are most beneficial in preserving the adsorption of nitrite and nitrate. The presence of dilute acetic acid (diluted vinegar) and acid phosphate followed by sulfates of sodium and magnesium are least detrimental, in that order, to the adsorption process as compared to the 
Effect of Electrolytes on the Adsorption....

presence of neutral chloride and alkaline salts. These observations would aid in analytical works, and for decontamination applications concerning use of activated charcoal with respect to nitrite and nitrate.

\section{REFERENCES}

Abdul, A, Aberuagba, F (2005). Comparative Study of the Adsorption of Phosphate by Activated Charcoal from Corncobs, Groundnut Shells and Rice-Husks AU. J. Tech. 9(1): 59-63.

Afkhami, A., Tayyebeh, M., Karimi, Z (2007). The effect of acid treatment of carbon cloth on the adsorption of nitrite and nitrate ions. J. Hazard. Mater. 144(1-2):427-431.

Ahalya, M., Kamamadi, R.D., Ramachandra, T.V (2005). Biosorption of chromium (VI) from aqueous solutions by the husk of Bengal gram (Cicer arientinum). Electron. J. Biotechn. $8(3)$,

Anonymous (2008a). Position Statements: SingleDose Activated Charcoal. The American Academy of Clinical Toxicology,

http://www.clintox.org/Pos_Statements/Charcoal.htm 1

Anonymous (2008b). Are your fish really suffering from disease? Toxic Nitrogen Compounds, http://www3.sympatico.ca/drosera1/fish/illness . htm

Batheja, K., Sinha, A.K., Seth, G (2009). Studies on water treatment for removal of nitrate. Asian J. Exp. Sci. 23(1):61-66.

CECW-E (2001). Engineering and Design Adsorption Design Guide,

http://www.usace.army.mil/usacedocs/design_guides/dg 1110-1-2/contents.htm

Chen, J.P., Lin, M. (2001). Surface charge and metal ion adsorption on an H-type activated carbon: experimental observation and modeling simulation by the surface complex formation approach. Carbon 39(10):1491-1504.

Gennaro, A.R (2000). Remington: The Science and Practice of Pharmacy, $20^{\text {th }}$ Edn. Volume II. Lippincott Williams \& Wilkins, New York.

Hoegberg, L.C.G., Angelo, H.R., Christophersen, A.B., Christensen, H.R (2002). Effect of ethanol and $\mathrm{pH}$ on the adsorption of acetaminophen (paracetamol) to high surface activated charcoal, in vitro studies. J. ToxicolClin. Toxic. 40(1):59-67.
Kadirvelu, K., Namasivayam, C (2000). Agricultural by-products as metal adsorbents: sorption of lead (II) from aqueous solutions onto coir-pith carbon. Environ.Technol. 21(10):1091-1097.

Mir, S.A (2008). A rapid technique for determination of nitrate and nitric acid by acid reduction and diazotization at elevated temperature. Anal. Chim. Acta 620: 183-189.

Mir, S.A (2009). Extraction of $\mathrm{NO}_{\mathrm{x}}$ and determination of nitrate by acid reduction in water, soil, excreta, feed, vegetables and plant materials J. Appl. Sci. Environ. Manage.13 (3): $57-63$

Misra, P.C., Patel, R.K (2009). Use of agricultural waste for the removal of nitrate-nitrogen from aqueous medium. J. Environ. Manage. 90(1): 519- 522.

Mizuta, K., Matsumoto, T., Hatate, Y., Nishihara, K., Nakanishi, T (2004). Removal of nitratenitrogen from drinking water using bamboo powder charcoal. Bioresource Technol. 95(3):255-257.

Orisakwe, O.E., Afonne, O.J., Agbasi, P.U., Ilondu, N.A., Ofoefule, S.I., Obi, E (2001). Adsorptive capacity of activated charcoal for rifampicin with and without sodium chloride and sodium citrate. Biol.Pharm. Bull. 24(6): 724-726.

Ozturk, N., Bektas, T.E (2004). Nitrate removal from aqueous solution by adsorption onto various materials. J. Hazard. Mater. 112(1-2):155-162.

Rahman, M.A, Asadullah, M, Haque, M.M, Motin, M.A., Sultan, M.B, Azad M.A.K (2006). Preparation and characterization of activated charcoal as an adsorbent. J. Sur. Sci. Techn. 22(3-4): 133-140.

Rocca, C.D., Belgiorno, V., Meric, S (2007). Overview of in-situ applicable nitrate removal processes. Desalination 204(1-3):46-62.

Zho, X. S., Choo, K.H., Park, J.M (2006). Nitrate removal from contaminated water using polyelectrolyte-enhanced ultrafiltration. Desalination 193(1-3): 350-360. 